\title{
Piotr Kubiński
}

Uniwersytet Warszawski

\section{Emersja - antyiluzyjny wymiar gier wideo}

Streszczenie. Niniejszy artykuł wprowadza kategorię emersji w grach wideo. Przez emersyjne autor proponuje rozumieć te elementy gry, które osłabiają wrażenie bezpośredniego uczestnictwa w wydarzeniach prezentowanych w grze (wrażenie to bywa nazywane immersją). Emersyjne są więc te czynniki, które zwracają uwagę na zmediatyzowany status akcji. Emersja może mieć charakter incydentalny (wtedy może być np. wynikiem nieprzewidzianego błędu w działaniu programu), powtarzalny (regularność występowania może wynikać np. z przyjętej konwencji gatunkowej) lub zaprojektowany. Ten ostatni wypadek zostaje poddany najbardziej szczegółowej analizie, ponieważ zaprojektowane czynniki emersyjne (a więc wprowadzane przez twórców z premedytacją) wykazują potencjał sensotwórczy i artystyczny. Rozumiane w ten sposób zaprojektowane zabiegi emersyjne przynoszą nową jakość, nieosiągalną za pośrednictwem innych, nieelektronicznych i nieinteraktywnych form ekspresji.

Słowa kuczowe. emersja, immersja, gry wideo, gry komputerowe, efekty emersyjne, czwarta ściana, ironia, dystans ironiczny

\section{Wprowadzenie}

elem niniejszego artykułu jest przedstawienie polskiemu czytelnikowi kategorii emersji, która stała się już przedmiotem osobnego studium w języku angielskim [Kubiński 2014]. Sformułowanie tej kategorii wyniknęło z dostrzeżenia pewnego paradoksu cechującego poetykę gier wideo oraz braku systematycznych i pogłębionych studiów dotyczących tego problemu.

Twórcy współczesnych gier komputerowych i konsolowych często projektują rozgrywkę (a zwłaszcza warstwę wizualną gry) w taki sposób, 
by ukryć przed graczem zmediatyzowany, a więc zapośredniczony charakter gry wideo [por. np. Ermi, Mäyrä 2005]. Projektowanie przekazu w taki sposób, by samo medium pozostawało z perspektywy użytkownika możliwie jak najbardziej przezroczyste, sprzyja wytworzeniu u gracza wrażenia bezpośredniości doświadczenia (według niektórych badaczy transparentność medium jest wręcz tego koniecznym warunkiem [Lombard, Ditton 2000: 5-6]). Wiąże się to wprost ze zjawiskiem określanym często mianem immersji (tu zwłaszcza w ujęciu Janet Murray [1997: 98-99]), a więc z doznaniem, którego istotą jest „zanurzenie zmysłowe” [Kluszczyński 2010: 57] w przestrzeni wygenerowanej komputerowo. Termin „immersja” cechuje się jednak współcześnie dużą wieloznacznością, słowo to jest używane przez badaczy w różny, czasem nawet sprzeczny sposób (w stanie badań da się wskazać przynajmniej kilkanaście różnych użyć tej kategorii, co sprawia, że przestaje być ona operatywna - na ten problem celnie zwraca uwagę Gordon Calleja [2011: m.in. s. 20-21]). Ograniczona objętość artykułu nie pozwala w satysfakcjonujący sposób rozstrzygnąć problemu definicji tej spornej kategorii (co nie jest notabene przedmiotem niniejszego tekstu), więc nie będę się do niej odwoływał w niniejszym artykule1. Aby uniknąć zarzutu o brak precyzji, ograniczę się tu do stwierdzenia, że głównym celem ukrywania czy też maskowania przez twórców zmediatyzowanego charakteru rozgrywki jest próba wywołania w graczu uczucia rzeczywistej „obecności w świecie generowanym komputerowo, a nie tylko [wrażenia - P.K.] używania komputera" [Ermi, Mayra 2005: 4].

W swoich badaniach postanowiłem skoncentrować się na tych składnikach gry, które - na przekór zarysowanej powyżej tendencji - wydobywają na pierwszy plan zapośredniczony charakter rozgrywki i świata diegetycznego ${ }^{2}$. Do nazwania tych czynników zaproponowałem termin "emersja” (przez analogię do etymologii terminu „immersja” sięgnąłem po łaciński czasownik emergo, emergere oznaczający 'wynurzać się') oraz określenia "Czynniki emersyjne" lub „elementy emersyjne".

Na tym poziomie największej ogólności emersja jest kategorią stosunkowo pojemną, nazywa pewien mechanizm przejawiający się na różnych

Różne ujęcia immersji można znaleźć np. w pracach: Ryan 2001; Douglas, Hargadon 2001; Slater 2003; Jennett 2008; Prazjner 2009.

2 Przez diegezę rozumiem tutaj przestrzeń fabularną, której w ujęciu Aarsetha [2003: 2] odpowiada „świat gry”. 
płaszczyznach gry, a tym samym obejmuje cały katalog zjawisk o zróżnicowanym statusie. Czynniki emersyjne w grze mogą mieć charakter:

- incydentalny - wówczas można je najczęściej określić jako przypadkowe, ich występowanie jest w dużym stopniu nieprzewidywalne i zdeterminowane przez czynniki technologiczne;

- powtarzalny - wtedy ich regularne występowanie w grze może być np. efektem ubocznym przyjętej konwencji gatunkowej;

- zaprojektowany - w takim wypadku element wydobywający medialność gry został wprowadzony przez twórców z premedytacją, najczęściej w celu osiągnięcia precyzyjnie określonego efektu.

Ostatni zaproponowany typ wydaje się najbardziej frapujący i najbardziej doniosły z perspektywy badacza, ponieważ tak rozumiane czynniki emersyjne stają się w rękach twórców narzędziem ekspresji twórczej, mogą wnosić do gier ładunek artystyczny, wykazują daleko idące analogie z technikami i mechanizmami artystycznymi typowymi zwłaszcza dla twórczości postmodernistycznej, rozpoznanymi w tradycji badań literaturoznawczych czy filmoznawczych. W tym sensie zaprojektowane czynniki emersyjne należy postrzegać jako nową manifestację wysoko cenionej tendencji kulturowej.

\section{Czynniki incydentalne}

Te czynniki emersyjne, które określam mianem incydentalnych, należy uznać za najbardziej prozaiczne - jako takie nie domagają się pogłębionego opisu. Czytelnego przykładu dostarczają wszelkiego rodzaju usterki techniczne, wynikające z niedoskonałości samego programu lub z błędów w działaniu hardware'u. Takim błędem może być chociażby zniknięcie fragmentu ciała bohatera, nieprawidłowe wyświetlenie jakiejś tekstury (np. jej kolorów), wzajemne przenikanie się postaci, skrajna deformacja danego obiektu lub dziwne (tzn. niezgodne z zasadami fizyki i jednocześnie w żaden sposób nieumotywowane fabularnie) zachowanie jakiegoś elementu otoczenia. Bardzo drastycznie ujawnia to fasadowość scenografii i demaskuje sposób konstrukcji (a więc i k rea c yj no ść) świata diegetycznego oraz jego ścisłą zależność od elektronicznego urządzenia (takiego jak komputer czy konsola) wraz z jego zawodną naturą związaną z wieloma jednostkowymi czynnikami technicznymi. Gracz narażony na tego typu od- 
krycie uświadamia sobie, że ma do czynienia z i l u z ją bezpośredniego uczestnictwa, a nie rzeczywistą bezpośredniością. W istocie użytkownik nigdy nie ma przecież faktycznie bezpośredniego dostępu do cyfrowej rzeczywistości, zawsze jest to dostęp zmediatyzowany, a więc zapośredniczony (choćby przez ekran, przez interfejs). I ten właśnie fakt zostaje wydobyty przez techniczną deziluzję mającą charakter incydentalny.

Podobny skutek przynosi taki błąd w grze, który za Alison McMahan [2003: 76] można by określić jako efekt „niedokończonego planu filmowego". Nierzadko zdarza się bowiem, że obiekty stanowiące część cyfrowej scenografii są projektowane i wykonywane nie w całości, lecz jedynie w tych fragmentach, które na pewno będą dla gracza widoczne: skoro projektant z całą pewnością wie, że gracz będzie oglądał dany obiekt tylko z konkretnej perspektywy (na przykład budynek będzie obserwowany wyłącznie od frontu), to taki obiekt może zostać wykonany jedynie w tej części, która jest rzeczywiście niezbędna. Co więcej, jeśli scenariusz gry zakłada, że bohater nie ma możliwości wejścia do danego budynku (drzwi są zamknięte i nie ma sposobu, by je otworzyć), to twórcy z oczywistych przyczyn często nie projektują ani nie wykonują jego wnętrz. Pozwala to pominąć te elementy danego obiektu, które i tak nie miałyby nigdy ukazać się oczom użytkownika. Bywa jednak, że gracz przez przypadek zauważa tę fasadowość scenografii - na przykład wskutek niedoskonałości pracy kamery, która przyjmuje perspektywę nieprzewidzianą przez autorów gry. W rezultacie obiekt, początkowo wyglądający na budynek, po przyjęciu przez gracza tej nieprzewidzianej perspektywy okazuje się na przykład jedynie pustym wielościanem, na którego wybrane boki nałożono odpowiednie tekstury (czyli grafikę zaledwie imitującą detale architektoniczne, a nie będącą faktyczną architekturą). Ubocznym efektem takiego przenikliwego spojrzenia okazuje się obnażenie i zdekomponowanie iluzji polegającej na wrażeniu bezpośredniej obecności w cyfrowej przestrzeni. Efekt ten można najbardziej obrazowo porównać do momentu, w którym sztukmistrz prestidigitator popełnia błąd i karty wysypują mu się z rękawa, a królik ucieka z kapelusza. Czar pryska. 


\section{Czynniki powtarzalne}

Osobno należy omówić te czynniki emersyjne, które wynikają z konwencji na przykład gatunkowych - i w związku z tym mają charakter powtarzalny. Z całego katalogu podobnych czynników wskażę dwa elementy gier, które odpowiadają tej kategorii i dobrze ją ilustrują: jeden na poziomie diegetycznym (fabularnym), a drugi - na poziomie metadiegetycznym.

Jedną z zalet gier wideo stanowiącą o popularności tego medium jest to, że w grach możliwe jest wytworzenie w zasadzie dowolnych modeli sytuacyjnych - między innymi dlatego gry elektroniczne tak chętnie były i są wykorzystywane do symulacji szkoleniowych. Model jednak - co oczywiste - zawsze odwzorowuje sytuację ze względu na wybrane, a nie wszystkie czynniki. Jak ujmuje to Piotr Sterczewski [2012: 216] „,model zawsze jest pewnym uproszczeniem rzeczywistości. W modelu pewne czynniki są brane pod uwagę, inne wykluczane, a jeszcze inne zostają poddane przybliżeniu". Uproszczenia wynikające z modelowej konstrukcji świata fabularnego i zachodzących w nim relacji są często czynnikiem, który może istotnie osłabiać wrażenie autentyczności cyfrowego doświadczenia. Ciekawego świadectwa tego problemu dostarcza tekst Piotra Puldziana Płucienniczaka [2013: 7], w którym autor emocjonalnie wytyka niedoskonałości systemów (modeli) ekonomicznych, jakie da się dostrzec w wielu grach cRPG. Według autora nie zachodzą w nich

żadnego rodzaju fakty ekonomiczne: ceny towarów są zwykle arbitralne i idiotyczne (bochen chleba kosztuje tyle, co stalowy hełm, sprzedaż tysiąca zdobycznych mieczy nie prowadzi do obniżenia cen na rynku), [...] zasoby regenerują się w nieskończoność (konta i magazyny kupców regenerują się regularnie bądź są wprost niewyczerpane).

Można zaryzykować twierdzenie, że niemal każdy choć trochę doświadczony gracz poczynił podobne obserwacje, należą one wręcz do potocznego i powszechnego doświadczenia gier (o czym świadczą np. liczne dyskusje internetowe oraz memy, graficzno-słowne komentarze rozpowszechniane przez sieć). Jeden z takich powszechnie znanych stereotypów powiada, że mapy w grach akcji (zwłaszcza w grach FPS) są często konstruowane w schematyczny sposób: duże, otwarte przestrzenie (areny) mogą 
zwiastować pojawienie się wyjątkowo potężnego przeciwnika (bossa). Zapowiedzią podobnego niebezpieczeństwa może być częstsze niż zwykle natrafianie przez gracza na przedmioty wspomagające (apteczki, amunicja).

Brak niuansów w projekcie poszczególnych aspektów cyfrowej rzeczywistości (w tym wypadku: stosowanie prostych, nie zawsze prawdopodobnych zależności ekonomicznych w grach cRPG) oraz powielanie schematycznych rozwiązań (np. konwencjonalne projektowanie map w grach FPS) znajdują naturalne uzasadnienie. Uproszczone rozwiązania pozwalają skrócić (a więc uczynić tańszym) proces produkcji, zdeterminowanej przecież przez czynniki finansowe - z drugiej jednak strony, jeśli schematyczne rozwiązania nadmiernie rzucają się w oczy, mogą istotnie wpływać na odbiór gry. Nie znaczy to, że muszą zmniejszać zaangażowanie w rozgrywkę (bywa, że jest wręcz przeciwnie: powielanie sprawdzonych wzorów pozwala graczowi łatwiej identyfikować stojące przed nim zadania, a przez to bardziej koncentrować się na ich efektywnym wykonaniu) - wydobywają jednakże kreacyjny charakter gry, a więc w mniejszym lub większym stopniu odzierają doświadczenie gracza z iluzji bezpośredniości.

Konwencjonalne, powtarzające się rozwiązania, które wydobywają medialny charakter gry, da się wskazać nie tylko na poziomie diegezy, lecz także elementów metafabularnych. Wyraźnym tego przykładem jest graficzny interfejs użytkownika, który w swojej najbardziej konwencjonalnej postaci należy do płaszczyzny ekranowej i nie jest częścią diegezy. Przykładem takiego rozwiązania jest celownik widoczny na środku ekranu lub pasek zdrowia - w obydwu wypadkach są to konwencjonalne znaki wizualne stanowiące istotną część identyfikacji wizualnej gier³. Jednocześnie jednak tak zaprojektowany graficzny interfejs użytkownika wydobywa (niefabularną) płaszczyznę ekranu, a w rezultacie - podkreśla zmediatyzowany charakter gry. Oczywiście emersyjne działanie takich znaków wizualnych ma charakter ograniczony i z całą pewnością nie jest bezwzględne - wynika to $z$ faktu, że takie elementy ekranowe są skonwencjonalizowane; na mocy swojej powtarzalności stały się (przynajmniej do pewnego stopnia) oczywistością, której raczej nie poddaje się refleksji . W efekcie gracze raczej nie zadają sobie pytania: „gdzie właściwie znajduje się pasek zdrowia?" albo „czy

Na temat znakowej natury interfejsów zob. Kubiński 2013.

4 Emersyjne działanie interfejsów poddaję dokładnej analizie w osobnym studium w niniejszym tomie, zob. artykuł Strategie estetyczne w projektowaniu graficznych interfejsów użytkownika w grach wideo - wobec emersji. 
bohater widzi ekranową informację o zapasie amunicji?" (tak jak pewną oczywistością niereflektowaną w codziennym użyciu jest np. prostokątny kształt ekranu kinowego czy - dla czytelnika z europejskiego kręgu kulturowego - zasada czytania tekstu od lewej do prawej strony).

\section{Czynniki zaprojektowane}

Za niewątpliwie najciekawsze zjawiska emersyjne należy uznać te, które nie są konsekwencją ani usterki technicznej, ani konwencji wykorzystanej w grze, ale zostały wprowadzone do gry z premedytacją, w celu wywołania określonego efektu (np. estetycznego, komunikacyjnego).

Do najbardziej podstawowych i rozpowszechnionych zarazem zabiegów tego typu należy akt burzenia czwartej ściany - znany nie tylko z gier, lecz także z filmu, komiksu czy teatru. Chwyt ów polega na obdarzeniu bohatera fikcji szczególnego rodzaju ponaddiegetyczną samowiedzą (auto-meta-wiedzą?). Dzięki temu postać fabularna zdaje sobie sprawę z tego, że jest częścią fikcji zapośredniczonej przez medium, lub na przykład komentuje reguły i konwencje rządzące komunikatem, w którym występuje. Całego katalogu aktów burzenia czwartej ściany dostarcza postać Deadpoola, dla której jest to gest charakterystyczny, stanowiący istotę jej tożsamości. W grach, w których występuje, bohater ten często zwraca się bezpośrednio do gracza. Widać to na przykładzie Deadpool: The Video Game [High Moon Studios 2013], gdzie już w najbardziej wstępnej części gry kilkakrotnie adresuje on swoje wypowiedzi wprost do użytkownika (np. „W mojej grze dostajesz punkty za zabijanie przeciwników” albo "Hej, graczu, otwórz menu rozwoju i zobacz, co możemy kupić" ${ }^{5}$ ) i komentuje mechanizmy obecne w grze (np. to, że gracz zdobywa punkty, nazywa "koniecznym systemem progresji"). Przykłady pochodzące $z$ tej jednej nawet gry można by długo mnożyć - istotne jest jednak to, co stanowi ich wspólny mianownik. Ich głównym celem jest przede wszystkim wywołanie zaskoczenia i rozbawienia użytkownika (tym bardziej że wypowiedzi Deadpoola mają najczęściej charakter nie tylko autozwrotny, lecz także głęboko ironiczny). Ponieważ jednak zabieg ten wtórnie zwraca uwagę gracza na konwencjonalny cha-

5 Wszystkie cytaty z gry Deadpool: The Video Game przytaczam we własnym tłumaczeniu. 
rakter mechanizmów rządzących grą, to jego działanie ma charakter emersyjny.

Akt burzenia czwartej ściany jest tylko jednym z wielu możliwych wariantów omawianego zjawiska. Innym przykładem emersji wprowadzanej do gry celowo może być kreowanie dystansu ironicznego w obrębie komunikatu. Odnoszę się tu jednak nie do klasycznego rozumienia ironii werbalnej [Allemann 2002], ale do ironii rozumianej jako szczególny g e s t dystansu wobec rzeczywistości, który w twórczości artystycznej przejawia się m.in. w podkreślaniu dyskursywności dzieła [Mitosek 2013: m.in. 16-19, 25, 355]. Istotą zabiegu, który przedstawię poniżej, a który nazywam dystansem ironicznym, nie jest bowiem zakomunikowanie jakiejkolwiek treści przeciwstawnej - zamiast tego przemycone zostaje drugie, zupełnie nowe znaczenie, funkcjonujące niejako ponad tekstem. Zostaje wytworzony dystans wobec samego tekstu, wobec dyskursu wytwarzanego przez grę.

Czytelnego przykładu tego zjawiska dostarcza scena zawarta w czwartym akcie gry Wiedźmin [CD Projekt RED 2007]. W rozmowie z głównym bohaterem jego przyjaciel, bard Jaskier, zaczyna improwizować pieśń (zob. ilustracja poniżej): „Czekaj, czuję natchnienie... Tę burzę włosów każdy zna, na ustach dłoni chwiejny gest, tak, to Alina, to Alina, to Alina jest... Nie, coś mi tu nie pasuje..." [podkr. moje - P.K.].

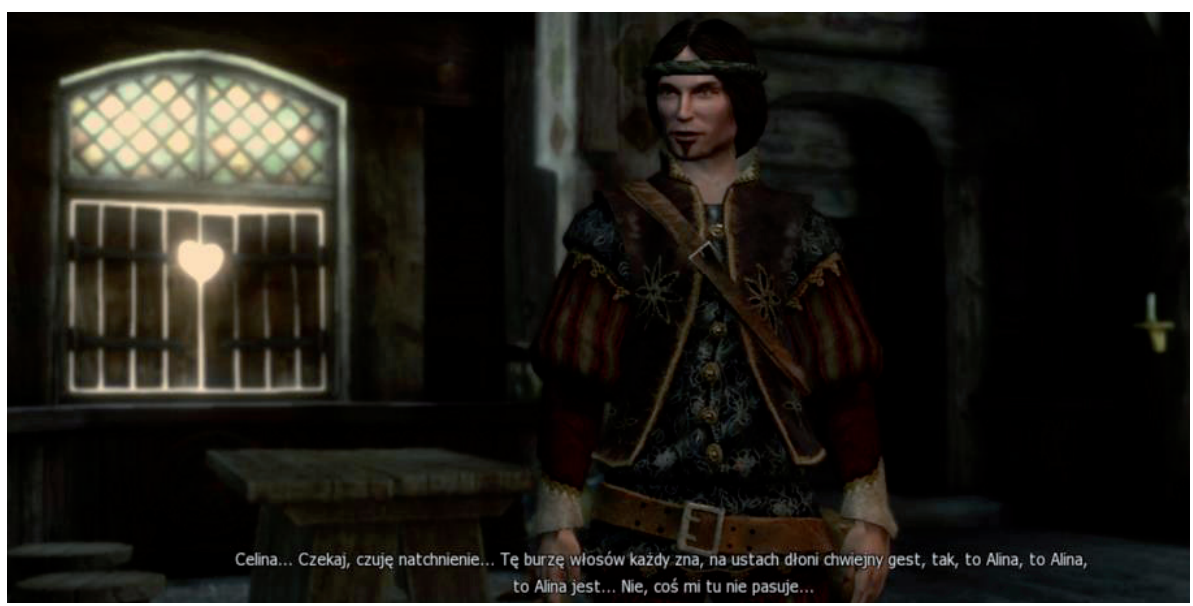

Ilustracja 1.Zrzut ekranu z gry Wiedźmin [CD Projekt RED 2007]

W cytowanej wypowiedzi można odnaleźć (zaznaczone przeze mnie kursywą) niemal dokładne przywołanie początkowych słów autentycznej 
piosenki Celina napisanej przez Stanisława Staszewskiego, a spopularyzowanej przez Kazika Staszewskiego wraz z grupą muzyczną Kult - jedyna różnica polega na tym, że w oryginalnym brzmieniu utworu pojawiało się imię Celina, a nie Alina

Na poziomie tekstowym można to przywołanie traktować po prostu jako zabieg transtekstualny, a mówiąc ściślej - jako relację intertekstualną (w wąskim znaczeniu zaproponowanym w typologii Gérarda Genette'a $a^{7}$ ). Choć tekst oryginalny został przytoczony niedokładnie (nastąpiła zamiana imienia) i bez podania adresu źródłowego, to jednak odniesienie przytoczonego fragmentu nie podlega dyskusji (tym bardziej że Jaskier śpiewa ten tekst na melodię znaną z Celiny). Gracz ma tutaj zatem do czynienia z takim przywołaniem słów, które to przywołanie nie dość że nie ujawnia wprost swojej tożsamości, to jeszcze parafrazuje tekst źródłowy.

Samo wykorzystywanie takiej aluzyjnej parafrazy nie jest niczym nowym: podobne nawiązania bardzo często pojawiają się w dziełach artystycznych o charakterze silnie intertekstualnym ${ }^{8}$ - służą wtedy do zawiązania intelektualnej gry z odbiorcą i do generowania nowych pól interpretacyjnych oraz nowych znaczeń tekstu. Podobny mechanizm przynosi jednak szczególnie interesujące skutki w wypadku gier wideo - na ich odbiór rzutuje wszakże bardzo silnie model oparty na dążeniu do iluzji bezpośredniego, niezmediatyzowanego doświadczenia. Otóż do zrozumienia aluzji zawartej w przytoczonym fragmencie Wiedźmina niezbędna jest znajomość zewnątrztekstowego kontekstu kulturowego: popularnej piosenki zespołu Kult. Użytkownik musi sięgnąć do wiedzy ze świata niediegetycznego, aby zrozumieć to, z czym zetknął się w przestrzeni cyfrowej - jest zatem prowo-

6 Celina (słowa i muzyka - Stanisław Staszewski).

7 Genette ujmuje transtekstualność jako termin bardzo pojemny, zawierający w sobie „wszystko, co wiąże go [tekst - przyp. P.K.] w sposób widoczny bądź ukryty z innymi tekstami"; jednym z typów relacji transtekstualnych jest w tym ujęciu intertekstualność, oznaczająca "relację współobecności zachodzącą między dwoma bądź wieloma tekstami [...] najczęściej jako rzeczywistą obecność jednego tekstu w drugim" [Genette 2014: 7-8].

8 Termin intertekstualność (przetworzony później m.in. przez Genette’a) wprowadziła do badań literaturoznawczych Julia Kristeva. Powołując się na prace Michaiła Bachtina - który dostrzegał w tekstach żywioł dialogowości, wskazywał, że teksty są swoistymi mozaikami złożonymi z wielu głosów i powstającymi względem innych tekstów - Kristeva rozumiała intertekstualność jako sieć wzajemnych zależności pomiędzy tekstami [Kristeva 1983]. Na temat teorii intertekstualności zob. zwłaszcza: Głowiński 1992; Nycz 2000; Burzyńska 2007. 
kowany do wyjścia poza ramy ekranu, do przypomnienia sobie o fizycznej rzeczywistości, co przynosi efekt jednoznacznie emersyjny.

Zarówno w wypadku kreowania dystansu ironicznego, jak i burzenia czwartej ściany zabiegi te mają zazwyczaj na celu przede wszystkim wywołanie efektu humorystycznego. Techniki opierające się na emersji mogą jednak wnosić do gry poważniejszy ładunek znaczeniowy czy wręcz artystyczny - dzieje się tak szczególnie wtedy, gdy gra kwestionuje zasady, które nią rządzą, lub gdy podejmowane są próby tekstualizacji jej mechanizmów. Bardzo wyrazistego przykładu podobnych zabiegów dostarcza The Stanley Parable [Galactic Cafe 2013]. Jej użytkownik wciela się w niemego bohatera imieniem Stanley - akcja gry toczy się w biurze, w którym Stanley jest pracownikiem numer 427; na początku rozgrywki okazuje się jednak, że w całym biurze nie ma śladu po pozostałych pracownikach. Poczynaniom bohatera sterowanego przez gracza towarzyszą komentarze i podpowiedzi wygłaszane przez Narratora (np. „Czując wzbierające niedowierzanie, Stanley zdecydował się pójść na górę do gabinetu szefa, w nadziei że znajdzie tam jakąś odpowiedź"').

Samo wykorzystanie głosu narratora nie jest zjawiskiem niespotykanym, dzieje się tak chociażby w grze Bastion [Supergiant Games 2011] by sięgnąć po jeden z wielu przykładów. Niezwykłe jednak jest to, że o ile narratorzy w grach pełnią zazwyczaj funkcję ponadfabularną, nie należą do świata diegetycznego i nie wpływają na bieg zdarzeń, o tyle status Narratora w The Stanley Parable szybko okazuje się wieloznaczny: nie tylko relacjonuje i objaśnia wydarzenia dziejące się na ekranie, lecz także zwraca się bezpośrednio do bohatera (już w czasie teraźniejszym, a nie przeszłym) i próbuje wpływać na jego decyzje. Narrator prowadzi z bohaterem (a właściwie z graczem) szczególnego rodzaju grę. Jego opowieść jest bowiem snuta w taki sposób, by gracz mógł postąpić na przekór słowom opowiadacza. Na przykład w jednym z węzłowych momentów fabuły bohater trafia do pokoju, w którym napotyka dwoje otwartych drzwi - Narrator komentuje to słowami: "Gdy Stanley stanął przed dwojgiem otwartych drzwi, przeszedł tymi po swojej lewej stronie”, jednoznacznie sugerując $w$ ten sposób graczowi, jak powinien postąpić. Ponieważ jednak drzwi po prawej stronie są również otwarte, to użytkownik The Stanley Parable staje wobec wyboru: może być posłuszny, ale może też postąpić wbrew słowom Narratora i zmusić go do zmiany opo-

9 Fragmenty The Stanley Parable przytaczam we własnym tłumaczeniu. 
wieści. Warto zwrócić uwagę, że jest to możliwe dlatego, że opowiadacz przedstawia w czasie przeszłym wydarzenia, które dopiero mają nastąpić. To umożliwia użytkownikowi wejście w swoistą grę z Narratorem, polegającą na sprawdzaniu granic jego elastyczności - umożliwia podejmowanie prób wykolejenia opowieści ${ }^{10}$.

Wieloznaczność roli Narratora przejawia się także w innych sytuacjach. W wybranych momentach fabularnych podejmuje on próby autokomentarza, refleksji na temat własnego statusu oraz funkcji samej opowieści, zwraca uwagę na konwencje gatunkowe i klisze wykorzystane w The Stanley Parable, np.

I wtedy być może najdziwniejsze z pytań przyszło Stanleyowi do głowy. Sam się zdziwił, że nie zastanowił się nad tym wcześniej: Dlaczego słyszę w swojej głowie głos, który opisuje wszystko, co robię i myślę? Teraz głos opisywał siebie jako rozważany przez Stanleya, który uznał to za szczególnie dziwne. - Śnię o głosie opisującym mnie myślącego o tym, jak głos relacjonuje moje myśli pomyślał.

Bardzo liczne chwyty, które należałoby określić jako autozwrotne, są także obecne na innych poziomach gry; ze względu na ograniczenia wynikające z objętości artykułu wskażę jedynie te widoczne już w samym menu początkowym gry. Jego znaczną część zajmuje... ekran przedstawiający analogiczne menu główne, w którym zawiera się następny ekran, a w nim następny. Każdy z tych ekranów zawiera duży napis "You are playing The Stanley Parable" (ang. 'Grasz w The Stanley Parable'), który można traktować jako wskazanie naczelnej zasady tej gry. Wedle tej zasady The Stanley Parable nie dąży do wywołania w graczu tradycyjnie rozumianej iluzji bezpośredniości. Zamiast tego na każdym kroku przypomina użytkownikowi,

10 Jeżeli gracz we wspomnianej sytuacji - wbrew woli Narratora - wybierze drzwi po prawej, Narrator powie: „To nie była właściwa droga do sali konferencyjnej, z czego Stanley doskonale zdawał sobie sprawę. Być może najpierw chciał zajrzeć do pokoju socjalnego, żeby trochę się nim pozachwycać". W tej krótkiej wypowiedzi ujawnia się elastyczność Narratora, który usiłuje kształtować opowieść w taki sposób, by miała ona sens mimo niesubordynacji gracza. Czytelna jest tu także kpina sugerująca, że gracz nie ma w istocie żadnego powodu, by wykazywać się nieposłuszeństwem (pokój socjalny jest tu bowiem najzupełniej zwykłym pomieszczeniem i nie ma w nim niczego, co warto by podziwiać). To kolejny przejaw gry toczącej się między Narratorem a graczem. 
że ma on do czynienia właśnie z grą. Doświadczenie zostaje więc przeniesione na inny poziom, poziom krytycznej zabawy z medium i jego regułami. Mechanizm ten jest jednoznacznie emersyjny. Znowu - nie musi to oznaczać mniejszego zaangażowania użytkownika, zaangażowanie to nabiera jednak innego, krytycznego charakteru.

Zabiegi wskazane w The Stanley Parable (oraz szeroki repertuar innych chwytów stosowanych w tej grze) oczywiście mogą wywoływać i wywołują rozbawienie. Pełnią one jednak znacznie ważniejszą funkcję niż tylko humorystyczna. Okazują się one realizacją ponowoczesnej strategii artystycznej polegającej na kwestionowaniu przez dzieło: tworzywa, ograniczeń wynikających z natury samego medium oraz obowiązujących w jego obrębie konwencji. Dzięki nie jednorazowemu, ale regularnemu sięganiu po techniki emersyjne The Stanley Parable przekształca się w niezwykły komentarz do gier wideo w ogóle - niezwykły tym bardziej, że sam będący grą.

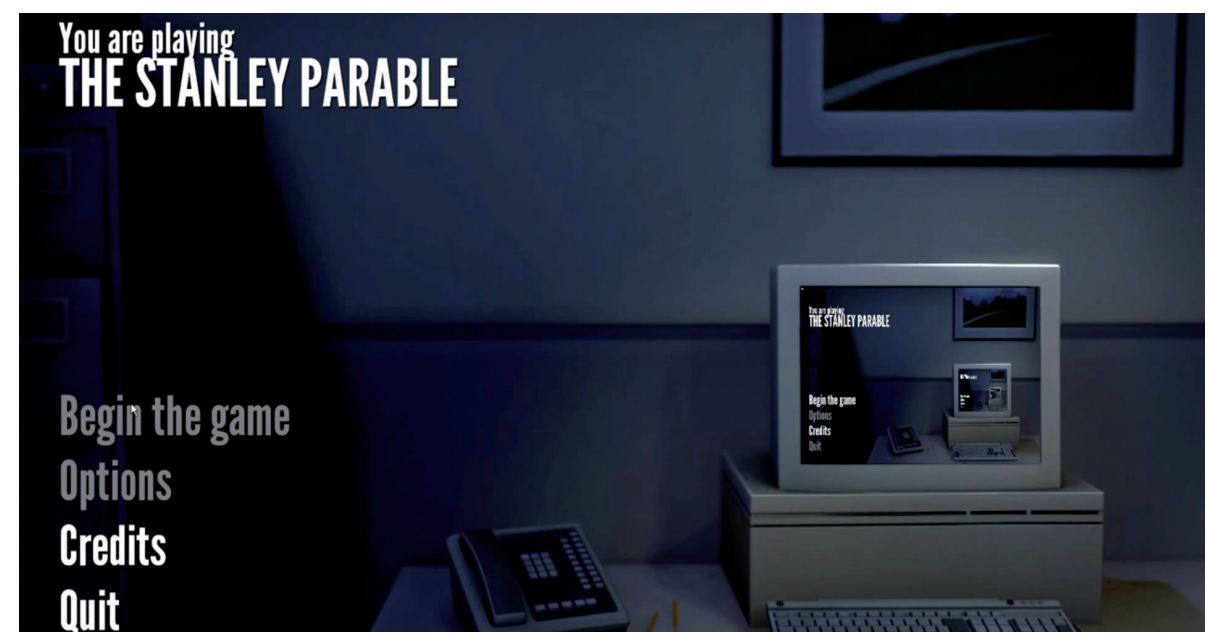

Ilustracja 2.Zrzut ekranu przedstawiający menu początkowe w The Stanley Parable. Zawarty tu napis „You are playing The STANLEY PARABLE” oraz powielenie tego samego menu na kolejnym monitorze wskazują na autotematyzm jako dominantę kompozycyjną gry

\section{Podsumowanie}

Zbiór mechanizmów emersyjnych przytoczonych i zanalizowanych w niniejszym artykule z pewnością nie wyczerpuje całego katalogu tego typu 
zjawisk - wskazuje raczej na najważniejsze przejawy emersyjności i główne powody jej występowania. Mogą one wynikać z ograniczeń samego przekaźnika lub niedoskonałości skonstruowanego w jego obrębie komunikatu; mogą być rezultatem konwencji gatunkowej przyjętej w danej grze; wreszcie - emersja może stanowić narzędzie do wywołania w użytkowniku określonego doświadczenia estetycznego czy komunikacyjnego.

Tak przedstawiona emersyjność okazuje się żywiołem bardzo silnie obecnym w omawianym medium - i równie silnie determinującym kształt powstających w jego obrębie dzieł - a więc będącym ważnym wyznacznikiem poetyki gier elektronicznych. Jednocześnie w stanie badań (zarówno polskim, jak i światowym) brakuje ujęć, które problematyzowałyby to zagadnienie: poszczególni badacze dostrzegali wybrane aspekty emersyjności (rzecz jasna, nie używając tego określenia), nie dostrzegając jednak ich wspólnego mianownika, którym jest antyiluzyjność - czasami celowo wprowadzana do takiego nowomedialnego tekstu kultury. Zdarza się bowiem, że emersja jest wywoływana z premedytacją -, by spowodować efekt, który okaże się znaczący w percepcji całego utworu.

Choć więc czynniki emersyjne przy odbiorze wyłącznie ludycznym często mogą wydawać się elementami niepożądanymi, to jednak w istocie da się w nich dostrzec bardzo duży potencjał sensotwórczy i artystyczny. Emersja wnosi bowiem dodatkowy dyskurs, przebiegający na pograniczu świata diegetycznego i świata użytkownika. Wytworzenie tej dodatkowej płaszczyzny - dodatkowego poziomu gry z odbiorcą i z jego przyzwyczajeniami oraz oczekiwaniami - może wnieść ładunek artyzmu. Nie polega on jednak na prostej estetyzacji świata gry, ale na myśleniu kategoriami ironicznej czy też deziluzyjnej sztuki ponowoczesnej, które to kategorie zostają przefiltrowane przez poetykę gier elektronicznych. W ten sposób zabiegi emersyjne mogą przynieść - i przynoszą - nową jakość, nieosiągalną za pośrednictwem innych, nieelektronicznych i nieinteraktywnych form ekspresji.

\section{Emersion - Anti-illusionary Dimension of Videogames}

Summary. This article presents the category of emersion in videogames. The author of this article understands emersion as an experience of such elements of a game that weaken the impression of non-mediated participation in events presented in the game (some researchers call this impression 
"immersion"). Emersive elements of the game reveal the mediated character of the action the player takes part in. Emersion may have varied status: it may be incidental (e.g. when it is a result of an unforeseen glitch), repeatable (e.g. as a result of a mechanism typical for a specific genre) or designed. The last case seems to be the most interesting one, because designed emerisve elements may provide meaningful or artistic results. Designed emersive factors bring new possibilities of creation, which are not achievable through the non-digital and non-interactive forms of expression.

Keywords: emersion, immersion, videogames, computer games, emersive effects, fourth wall, irony, ironic distance.

\section{Bibliografia}

\section{Książki}

Allemann Beda. 2002. O ironii jako o kategorii literackiej. Tłum. M. Dramińska-Joczowa. [w:] M. Głowiński (red.), Ironia. Gdańsk: Słowo/obraz terytoria.

Burzyńska Anna. 2007. Poststrukturalizm. [w:] A. Burzyńska, M.P. Markowski. Teorie literatury XX wieku. Kraków: Wydawnictwo Znak.

Calleja Gordon. 2011. In-Game: From Immersion to Incorporation. Cambridge-London: The MIT Press.

Genette Gérard. 2014. Palimpsesty. Literatura drugiego stopnia. Tłum. T. Stróżyński, A. Milecki. Gdańsk: Słowo/obraz terytoria.

Głowiński Michał. 1992. O intertekstualności. [w:] M. Głowiński, Poetyka i okolice. Warszawa: PWN.

Kristeva Julia. 1983. Słowo, dialog i powieść. Tłum. W. Grajewski. [w:] E. Czaplejewicz, E. Kasperski (red.), Bachtin. Dialog - język - kultura. Warszawa: PWN.

Kluszczyński Ryszard W. 2010. Sztuka interaktywna. Od dzieła-instrumentu do interaktywnego spektaklu. Warszawa: Wydawnictwa Akademickie i Profesjonalne.

Kubiński Piotr. 2014. Immersion vs. emersive effects In videogames. [w:] D. Stobbart, M. Evans (red.), Play, Theory, and Practice: Engaging with Videogames. Oxford: Inter-Disciplinary Press.

McMahan Alison. 2003. Immersion, Engagement, and Presence: A Method for Analyzing 3-D Video Games. [w:] M.J.P. Wolf, B. Perron (red.), The Video Game, Theory Reader. New York: Routledge.

Mitosek Zofia. 2013. Co z tq ironiq̨? Gdańsk: Słowo/obraz terytoria. 
Murray Janet. 1997. Hamlet on The Holodeck: The Future of Narrative In Cyberspace. Cambridge MA: The MIT Press.

Nycz Ryszard. 2000. Intertekstualność i jej zakresy: teksty, gatunki, światy. [w:] R. Nycz. Tekstowy świat. Poststrukturalizm a wiedza o literaturze. Kraków: Universitas.

Prajzner Katarzyna. 2009. Tekst jako świat i gra. Modele narracyjności w kulturze współczesnej. Łódź: Wydawnictwo Uniwersytetu Łódzkiego.

Ryan Marie-Laure. 2001. Narrative as Virtual Reality. Immersion and Interactivity In Literature and Electronic Media. Baltimore-London: Johns Hopkins University Press.

\section{Artykuły}

Jennett Charlene, et. al. 2008. Measuring and Defining The Experience of Immersion In Games. „International Journal of Human-Computer Studies” nr 66, s. 641-661.

Kubiński Piotr. 2013. Znakowy charakter graficznych interfejsów użytkownika. „Przegląd Humanistyczny" 4/2013, s. 73-81.

Płucienniczak Piotr Puldzian. 2013. Formacja fantastyczna: przygoda jest praca. „Ha!art" 43, s. 6-10.

Sterczewski Piotr. 2012. Czytanie gry. O proceduralnej retoryce jako metodzie analizy ideologicznej gier komputerowych. „Teksty Drugie” nr 6/2012, s. $210-228$.

\section{Źródła internetowe}

Aarseth Espen. 2003. Playing Research:Methodological approaches to game analysis. http://hypertext.rmit.edu.au/dac/papers/Aarseth.pdf, 30.07.2014.

Ermi Laura, Mäyrä Frans. 2005. Fundamental Components of Gameplay Experience: Analysing Immersion. http://people.uta.fi/ tlilma/gameplay_experience. pdf, 30.07.2014.

Lombard Matthew, Ditton Theresa B., et al. 2000. Measuring presence: a literaturebased approach to The development of a standardized paper-and-pencil instrument. www.socialinformation.org/readings/presence/measruing\%20presence.pdf]Lombard, 30.07.2014. 
Slater Mel. A Note on Presence Terminology. http://publicationslist.org/data/melslater/ref-201/a\%20note\%20on\%20presence\%20terminology.pdf, 30.07.2014.

\section{Przywołane gry}

- Bastion [Supergiant Games 2011]

- Deadpool: The Video Game [High Moon Studios 2013]

- The Stanley Parable [Galactic Cafe 2013]

- Wiedźmin [CD Projekt RED 2007] 